\title{
Drinking Water Quality Influence to the Peasants' Morbidity in the Ukrainian Settlements (by the Results of Sociological Survey and Correlation Analyses)
}

\author{
Hryhorenko Liubov Victorovna \\ Dnipropetrovsk Medical Academy of the Ministry of Health of Ukraine, Dnipro, Ukraine
}

Email address:

ask_lubov@mail.ru

\section{To cite this article:}

Hryhorenko Liubov Victorovna. Drinking Water Quality Influence to the Peasants' Morbidity in the Ukrainian Settlements (by the Results of Sociological Survey and Correlation Analyses). International Journal of Statistical Distributions and Applications.

Vol. 3, No. 3, 2017, pp. 38-46. doi: 10.11648/j.ijsd.20170303.13

Received: March 12, 2017; Accepted: March 28, 2017; Published: October 31, 2017

\begin{abstract}
During 2012 - 2014 years our study showed significant trend towards growth useage of drinking water purifiers, mostly, for drinking purposes, among peasants and city-dwellers. Peasants - residents of Dnepropetrovsk region (Ukraine) have been performed deterioration quality of piped drinking water as well as smell $-22.6 \%$, color $-14.6 \%$, rust $-13.3 \%$, precipitate $-8.0 \%$, turbidity and suspended solids $-10.6 \%$, taste and aftertaste $-13.3 \%$, foam and impurities $-10.6 \%(\mathrm{p}<$ 0.05 ). Minority of peasants $-6.66 \%$ consider "problem with drinking water quality does not exist". Our study indicates growth daily consumption of drinking water is related to peasants' population: from $2-5$ liters/daily (33.3\%) to $20-40$ liters/daily (33.3\%). In the article was shown influence some components of the chemical composition of potable water in the 6 rural tacsons of Dnepropetrovsk region ( $\mathrm{Zn}, \mathrm{Cu}, \mathrm{Mn}, \mathrm{pH}, \mathrm{F}, \mathrm{Al}$, ammonium nitrogen, nitrites, nitrates, oxidation) to the morbidity of 14 y.o. children such diseases as: blood circulation system, tumors, blood and blood organs, anemia, nervous system, congenital anomalies, i.e. blood circulation system $(\mathrm{p}<0.05)$. Correlation was significantly determined between general rigidity and iron on the potable water and blood and blood organs diseases, and anemia among children population in the majority of rural tacsons $(\mathrm{r}=0.58-0.79)$; between anemia - content of chlorides and sulfates in the centralized water sources $(\mathrm{r}$ $=0.87)(\mathrm{p}<0.05)$.
\end{abstract}

Keywords: Quality and Safety Indexes, Respondents, Questionnaire, Children, Correlation, Potable Water

\section{Introduction}

Drinking water and replacing sugary beverages with water also may help reduce obesity and dental problems among children and adolescents. New research [1] in the 2011-2012 school years, schools participating in the federally-funded National School Lunch Program describes how schools are meeting this requirement and provides insight about the cleanliness of drinking fountains. Key Findings In 2011$2012,86 \%$ of elementary, $87 \%$ of middle, and $89 \%$ of high school students attended schools that reported meeting the drinking water requirement. Only half of middle and high school students attended schools where the administrator reported that the drinking fountains were very clean. Administrators perceived the drinking fountains to be clean or very clean in $93 \%$ of middle schools and $91 \%$ of high schools. About one in four middle school and high school students attended schools where the administrator selfreported at least "a little" concern about the quality of water in the drinking fountains.

Reports of outbreaks in Canada and the United States (U.S.) indicate that approximately $50 \%$ of all waterborne diseases occur in small non-community drinking water systems (SDWSs). From a total of 1,995 citations, we identified 50 relevant articles reporting 293 unique outbreaks. Failure of an existing water treatment system (22.7\%) and lack of water treatment $(20.2 \%)$ were the leading causes of waterborne outbreaks in SDWSs [2].

Safe potable water is essential for good health. Worldwide, school-aged children especially in the developing countries 
are suffering from various water-borne diseases $[3,4,5]$. Among main sources of water pollution was chemical contamination of wells by heavy metals. The level of heavy metals in the tube well water samples were as follows: As from 1 to $55 \mu \mathrm{g} / \mathrm{L}, \mathrm{Fe}$ from 40 to $9890 \mu \mathrm{g} / \mathrm{L}$, and Mn from 10 to $370 \mu \mathrm{g} / \mathrm{L}$. Drinking water parameters of Magura district did not meet the requirement of the World Health Organization drinking water quality guideline, or the Drinking Water Quality Standards of Bangladesh [6].

Arsenic concentrations in groundwaters of the studied areas showed large variations, with mean As concentrations of $125 \mu \mathrm{g} / \mathrm{L}$ (range: from 0.20 to $1,301 \mu \mathrm{g} / \mathrm{L}$ ) in Bhagirathi sub-basin, $145 \mu \mathrm{g} / \mathrm{L}$ (range: from 0.20 to $891 \mu \mathrm{g} / \mathrm{L}$ ) in Padma-Meghna sub-basin, $209 \mu \mathrm{g} / \mathrm{L}$ (range: from 1.3 to 575 $\mu \mathrm{g} / \mathrm{L}$ ) in Chianan plain, and $102 \mu \mathrm{g} / \mathrm{L}$ (range: from 2.5 to 348 $\mu \mathrm{g} / \mathrm{L}$ ) in Lanyang plain groundwater. The concentrations of $\mathrm{Fe}$, and $\mathrm{Mn}$ are also highly variable, and are mostly above the WHO-recommended guideline values and local (Indian and Bangladeshi) drinking water standard [7].

Problem of providing drinking water guaranteed quality are widely inspread not only for European population [8, 9], but also in many regions of Ukraine, especially in the rural settlements of Dnepropetrovsk region [10,11]. Therefore, in the aspect of legal innovations in the field of preventive medicine the hygienic substantiation issues of bottled water useage among peasants and city - dwellers of Dnepropetrovsk region has become a vital necessity problem.

Purpose of research is scientific substantiation results of sociological survey and correlation analyses devoted to the influence of drinking water quality indicators to the peasants' morbidity in the rural tacsons of Dnepropetrovsk region for $2008-2013$ years.

\section{Materials and Methods}

\subsection{Sociological Survey, Carried out Among Population of Central Zone of Urbanization in Dnepropetrovsk Region}

In the first part of our study was used standardized "Questionnaire survey about quality of piped drinking water, which enters to the building (apartment)", which contained 25 questions. In the sociological survey were participated 150 respondents $(75$ - peasants and 75 city - dwellers). The basic criteria were: age of adult population (men and women), varied from 35 to 55 years; period of residence in this region - from 5 to 10 years and over 10 years; exposition of drinking water - from 5 to 10 years and over 10 years. Long - term period of residence was observed at the $76 \%$ of peasants and $77.3 \%$ of city - dwellers $(p<0.05)$. Most of our studies found that the quantity of respondents with up to 10 years period of water exposition was higher in both groups and varied from $22.6 \%$ to $24 \%$.

According to the results of sociological survey, average age of rural residents was $33.33 \pm 0.52$ years, compared with city - dwellers $-35.07 \pm 0.54$ years. All groups of respondents were devided by the gender $\left(p=0.220\right.$ criterion $\left.\chi^{2}\right)$ and age groups ( $\mathrm{p}=0.997$ by ANOVA) (table 1$)$.

In order to carry out objective indicators as well as quality of potable water we conducted functional zoning rural settlements of Dnepropetrovsk region into two groups: experimental and control. Experimental group covered over 2583.9 ha of agricultural territories (81\% of Dnepropetrovsk region), which was subdivided into 4 agricultural centers: Apostolovskyi, Kryvorozskyi, Pavlogradskyi and Nikopolskyi. Control zone covered Central zone of urbanization, which included $18 \%$ of territory of Dnepropetrovsk region, and industrial city Dnipro. Retrospective study covered 2012 - 2014 years. In our research was used such methods as retrospective studies, sociological, statistical. Statistical procedure carried out at the standard programs Microsoft Office Excel 2003 and Statistica [4]. Statistical indicators were: number of observations (n), average means (M), standard error (m), relative values (\%). The critical level of statistical significance ( $p$ ) for testing of statistical hypotheses were accepted by the criteria of Manna-Whitney, $\mathrm{t}$ - criterion student as well as $\mathrm{p} \leq 0.05, \mathrm{p} \leq 0.001$.

Table 1. Distribution of respondents by age and gender groups (absolute,\%).

\begin{tabular}{llll}
\hline \multicolumn{1}{l}{ Characteristic } & Peasants & City - dwellers \\
\hline \multirow{2}{*}{ Age, years } & $18-29$ & $31(41.3 \%)$ & $26(34.6 \%)$ \\
& $30-39$ & $24(32.0 \%)$ & $27(36 \%)$ \\
& $50-59$ & $16(21.3 \%)$ & $12(16 \%)$ \\
Totally & 60 and more & $1(1.3 \%)$ & $7(9.3 \%)$ \\
p & & $75(100 \%)$ & $3(4.0 \%)$ \\
Average age $(M \pm m)$ & $\mathrm{p}=0.220 *$ & $75(100 \%)$ \\
Gender & Men & $33.33 \pm 0.52$ years & $35.07 \pm 0.54$ years \\
& Women & $36(48.0 \%)$ & $43(57.3 \%)$ \\
Totally & & $75(100 \%)$ & $32(42.6 \%)$ \\
p & & $\mathrm{p}=0.997 * *$ & $75(100 \%)$ \\
\hline
\end{tabular}

Note. $* \mathrm{p}-$ significance of differences between groups by criterion $\chi^{2} ; * * \mathrm{p}-$ by dispersion analysis ANOVA $(\mathrm{p}<0.05)$.

\subsection{Correlation Analyses Some Indicators of Water Quality and Morbidity of Children in the Rural Tacsons of Dnepropetrovsk Region}

The second part of our research was devoted to the study of correlation links between some indicators of water quality in the centralized water supply sources and incidence of diseases among children population in the separated tacsons of Dnepropetrovsk region for 2008 - 2013 period. Objects of study were children - inhabitants of rural tacsons of Dnepropetrovsk region. Retrospective study covered the disease prevalence and assessment of morbidity among children population (under 14 years) in the rural tacsons of Dnepropetrovsk region for 2008 - 2013 years, on the basis of official statistical data copying documentation at the different institutions belongs to the Ministry of Health of Ukraine. 


\section{Study Findings and Discussion}

\subsection{Analyses of the Drinking Water Quality and Sanitary Conditions of Life at the Peasants and City-Dwellers, by the Results of Sociological Survey}

Our findings have been shown, that every 37 from 75 peasants, i.e. $49.3 \%$ of respondents drink only bottled water, as compared to the city - dwellers: 42 persons, i.e. $56 \%$ $(p<0.001)$. On the other hand, majority of peasants $50.6 \%$ weren't use bottled water $(\mathrm{p}<0.05)$. Rural population rarely used mineral water for drinking purposes, as shown $62.6 \%$ of peasants; the minority of peasants $-37.3 \%$ used mineral water for treatment purposes. Among city - dwellers only $61.3 \%$ didn't use mineral water for therapeutic purposes.

The second stage of our sociological servey was ranking adult population in both groups in order to study their point of view towards different types of bottled water and drinking water purifiers. On the first rank were $58.9 \%$ of peasants, which were used for drinking and cooking purposes bottled water, as compared to $41.1 \%$ of city - dwellers. On the second rank were $20.6 \%$ of peasants, who prefer to use domestic filters $(\mathrm{p}<0.05) ; 10 \%$ of respondents used unboiled tap water $(\mathrm{p}<0.05)$.

Respondents were proposed several answers to the question "Do You clean water immediately befor using?" Our study shows that majority of peasants $-32 \%$ prefer to use domestic filter, $24 \%$ of respondents were applied bottled water $(p<0.05)$. The minority of peasants carried out traditional methods of drinking water purification: $16 \%$ boiling; $17.3 \%$ drinking tap water $(\mathrm{p}<0.05) ; 10.6 \%-$ precipitation $(\mathrm{p}<0.05)$.

Similar trend was observed among city - dwellers. On the first rank were $33.3 \%$ of respondents, installing domestic filters; $29.3 \%$ of city - dwellers used different types of bottled water ( $\mathrm{p}<0.05)$; the least $17.3 \%$ of city inhabitants was defined to use boiled water; $12 \%$ - tap water without any additional purification $(\mathrm{p}<0.05) ; 8 \%$ - drinking water after precipitation $(\mathrm{p}<0.05)$.

At the prevalence of drinking water sources, related to population of rural settlements of Dnepropetrovsk region, we include wells and their frequency of using $-30.6 \%$. Tap water used only $56 \%$ of peasants $(p<0.001), 13.3 \%$ of respondents prefer to use local additional sources of surface water $(\mathrm{p}<0.05)$. Exposure of water from the given sources was reported by city - dwellers in the interview as well as: additional sources of surface water: $28 \%(\mathrm{p}<0.001)$; wells $5.33 \%$.

In the standardized interview we carried out distance from the source of water to the population residence. Based on the sociological servey, we considered, that $25.3 \%$ of peasants were requested $15-25$ meters; $57.3 \%$ of sources were located on the $30-50$ meters; $17.3 \%$ - up to 100 meters.

Most peasants were dissatisfied with following indicators of drinking water quality: $22.6 \%$ with smell, $14.6 \%$ with color $(\mathrm{p}<0.05), 13.3 \%$ with rust, $8.0 \%$ with precipitate, $10.6 \%$ with turbidity and suspended solids, $13.3 \%$ with taste and aftertaste $(\mathrm{p}<0.05), 10.6 \%$ with foam, poor quality and impurities. Only $6.66 \%$ of respondents were satisfied with good-quality of drinking water (Figure 1).

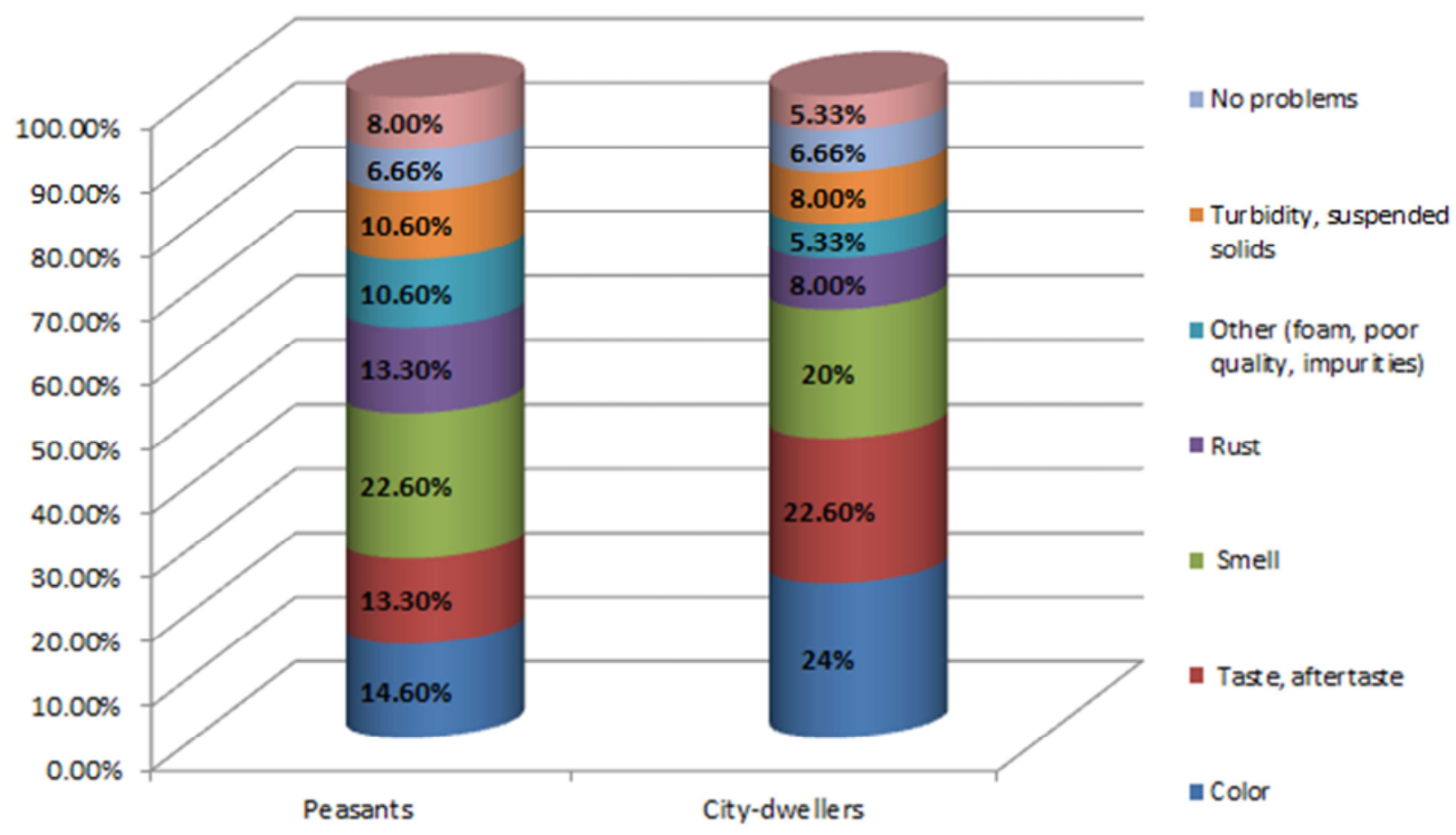

Figure 1. Basic problems, associated with using of tap drinking water among rural and urban residents in Dnipropetrovsk region. 
City - dwellers noted deterioration of drinking water color $24 \%$, taste and aftertaste $-22.6 \%$, smell $-20 \%$, precipitate $5.33 \%$, rust $-8.0 \%$, and others (turbidity and suspended solids) $-8.0 \%$. About $5.33 \%$ of respondents considered other reasons for deterioration of drinking water quality, such as foam and impurities. Only $6.66 \%$ of citizens were satisfied with a quality of drinking water $(\mathrm{p}=0.224)$ (table 2$)$.

Table 2. Respondents' answers from Central zone of urbanization on the question Describe problems, associated with using of drinking water in Your community (absolute, \%).

\begin{tabular}{lll}
\hline Proposed variant of answer & Peasants & City - dwellers \\
\hline Color & $11(14.6 \%)$ & $18(24 \%)$ \\
Taste, aftertaste & $10(13.3 \%)$ & $17(22.6 \%)$ \\
Smell & $17(22.6 \%)$ & $15(20 \%)$ \\
Rust & $10(13.3 \%)$ & $6(8.0 \%)$ \\
Other (foam, poor quality, impurities) & $8(10.6 \%)$ & $4(5.33 \%)$ \\
Turbidity, suspended solids & $8(10.6 \%)$ & $6(8.0 \%)$ \\
No problems & $5(6.66 \%)$ & $5(6.66 \%)$ \\
Precipitate & $6(8.0 \%)$ & $4(5.33 \%)$ \\
Totally (n=150) & $75(100 \%)$ & $75(100 \%)$ \\
$\mathrm{p}$ & $\mathrm{p}=0.224$ & \\
\hline
\end{tabular}

Note. $\mathrm{p}$ - significance of differences between respondents answers in the experimental and control groups by a criterion $\chi^{2}-$ Pearson.

Relation of residents from Central zone of urbanization in Dnipropetrovsk region to the different types of post-treated drinking water was presented in (table 3 - 5). Primary, 20.6\% of peasants used for drinking and cooking purposes bottled water, compared with $20 \%$ of city - dwellers $(p<0.05)$. Other respondents in the rural districts $(20.6 \%)$ used domestic filters for purification of drinking water. Significantly minority of respondents in both groups used for drinking purposes a tap water: $10 \%$ of peasants against $6.0 \%$ of city dwellers $(\mathrm{p}<0.05)$.
Table 3. Respondents' answers from Central zone of urbanization on the question Do you apply for drinking and cooking purposes bottled water?" (absolute,\%).

\begin{tabular}{lll}
\hline Proposed variant of answer & Peasants & City - dwellers \\
\hline Yes & $31(20.6 \%)$ & $30(20 \%)$ \\
No & $22(14.6 \%)^{*}$ & $15(10 \%)^{*}$ \\
Sometimes & $22(14.6 \%)^{*}$ & $30(20 \%)^{*}$ \\
Totally $(\mathrm{n}=150)$ & $75(100 \%)$ & $75(100 \%)$ \\
p & $\mathrm{p}<0.05$ & \\
\hline
\end{tabular}

Note. $\mathrm{p}$ - significance of differences between respondents answers in the experimental and control groups by a criterion $\chi^{2}-$ Pearson.

Table 4. Respondents' answers from Central zone of urbanization on the question Do you use domestic filter for purification of drinking water?" (absolute,\%).

\begin{tabular}{lll}
\hline Proposed variant of answer & Peasants & City - dwellers \\
\hline No & $28(18.6 \%)^{*}$ & $21(14.0 \%)^{*}$ \\
We have a separate tap for & $16(21.3 \%)^{*}$ & $23(15.3 \%)^{*}$ \\
drinking water & $31(20.6 \%)^{*}$ & $31(41.3 \%)^{*}$ \\
We have a filter pitcher & $75(100 \%)$ & $75(100 \%)$ \\
Totally $(\mathrm{n}=150)$ & $\mathrm{p}<0.05$ & \\
$\mathrm{p}$ & & \\
\hline
\end{tabular}

Note. $\mathrm{p}$ - significance of differences between respondents answers in the experimental and control groups by a criterion $\chi^{2}-$ Pearson.

Table 5. Respondents' answers from Central zone of urbanization on the question Do you use for drinking purposes a tap water?"(absolute,\%).

\begin{tabular}{lll}
\hline Proposed variant of answer & Peasants & City - dwellers \\
\hline Yes & $15(10 \%)$ & $9(6.0 \%)$ \\
No & $37(24.6 \%)^{*}$ & $42(28 \%)^{*}$ \\
Sometimes & $23(15.3 \%)^{*}$ & $24(16 \%)^{*}$ \\
Totally $(\mathrm{n}=150)$ & $75(100 \%)$ & $75(100 \%)$ \\
$\mathrm{p}$ & $\mathrm{p}<0.05$ & \\
\hline
\end{tabular}

Note. $\mathrm{p}$ - significance of differences between respondents answers in the experimental and control groups by a criterion $\chi^{2}-$ Pearson.

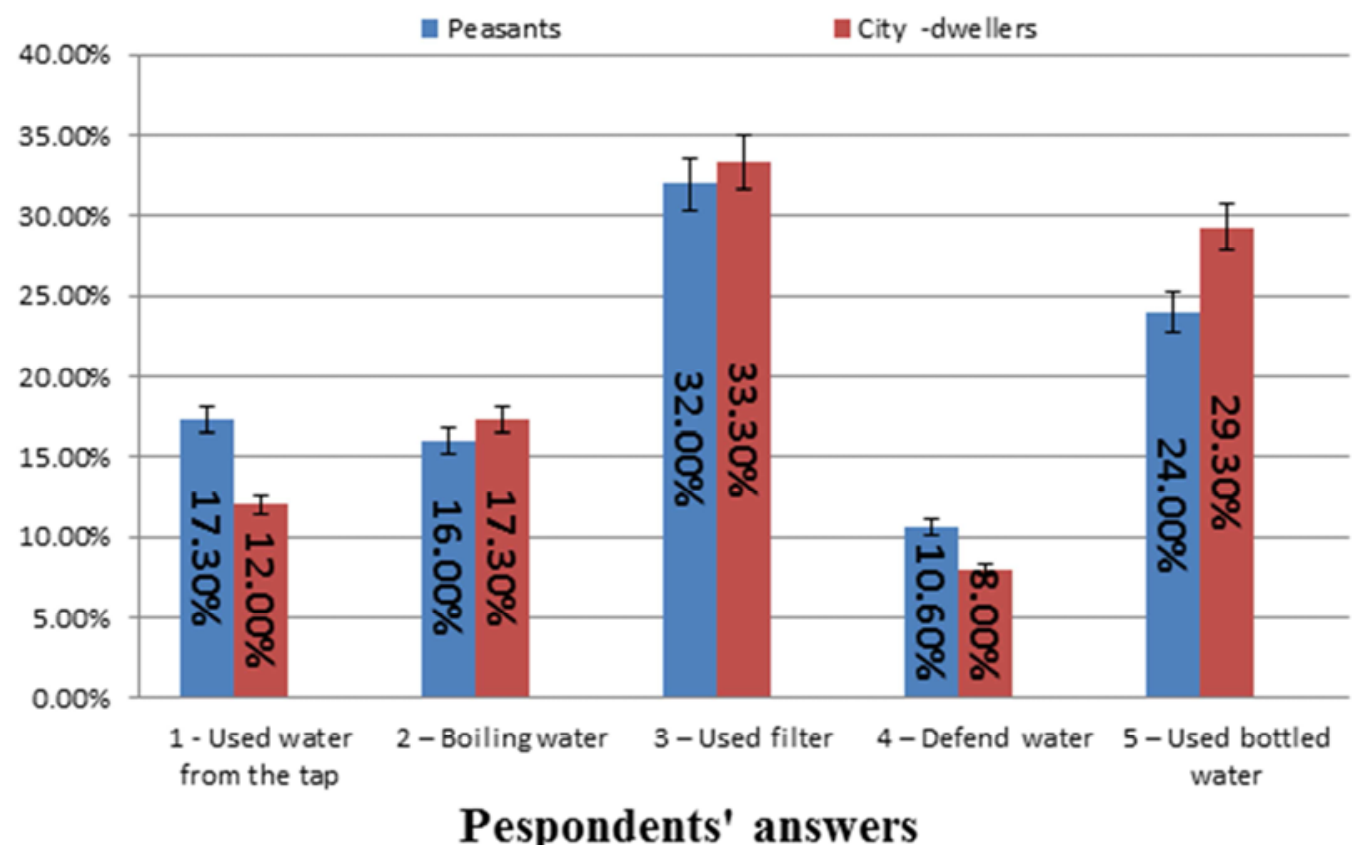

Figure 2. Frequency of respondents' answers in the experimental and control groups on the question: Do you purify water directly before using?"(P \pm mp\%). 
On the question "Do you purify water directly before using?" respondents were proposed several variants of answers. Results of our survey have been shown, that the vast majority of peasants $32.0 \%$ used domestic filter or the drinking bottled water $-24.0 \%$. Other peasants used traditional methods of water purification: $16.0 \%$ - boiling; $17.3 \%$ - tap drinking water; $10.6 \%$-defend water. As have been shown in (Figure 2), a similar trend was observed among the city - dwellers in Dnipro city.

Among the different types of drinking water purification, city - dwellers prefer the use a domestic filter $-33.3 \%$, or the bottled water $-29.3 \%$, while other part of respondents used the boiled water $-17.3 \%$, or the tap water $-12.0 \%$, and defend water $-8.0 \%$.

Water supply sources, used by the respondents in both groups, could be placed in the following ranked order. Peasants used drinking water from a network of water pipes $56 \%$, wells $-30.6 \%, 13.3 \%$ - from open reservoirs. City dwellers are significantly probably used water from local water pipe $-66.6 \%$ and $28 \%$ - from open reservoir, about $5.33 \%$ used drinking water from wells $(p=0.199)($ table 6$)$.

Table 6. Respondents' answers from Central zone of urbanization on the question What sources of water supply do you use in your community?" (absolute, \%).

\begin{tabular}{lll}
\hline Proposed variant of answer & Peasants & City - dwellers \\
\hline Rural (city) water supply & $42(56 \%)$ & $50(66.6 \%)$ \\
Well & $23(30.6 \%)$ & $4(5.33 \%)$ \\
Open pond & $10(13.3 \%)$ & $21(28 \%)$ \\
Totally (n=150) & $75(100 \%)$ & $75(100 \%)$ \\
$\mathrm{p}$ & $\mathrm{p}=0.199$ & \\
\hline
\end{tabular}

Note. $\mathrm{p}$ - significance of differences between respondents answers in the experimental and control groups by a criterion $\chi^{2}-$ Pearson.
According to the sociological survey, $25.3 \%$ of peasants had insufficient distance to a place of water supply - from 15 to 25 meters, which did not correspond to the Ukrainian National hygienic standards. On a distance from 30 to 50 meters were located sources of water supply at $57.3 \%$ of population in the experimental group and up 100 metres at $17.3 \%$ of the peasants, which was correspond to the hygienic standards. As shown in (Figure 3), respondents in both groups were covered with central sewerage system: $65.3 \%$ of rural and $85.3 \%$ of urban population. Generally, 26 peasants (34.6\%) and 11 city - dwellers $(14.6 \%)$ were covered with decentralized sewage system.

On the next step of our research we carried out household conditions for residents in both groups of supervision. It was established, that 49 peasants having good sanitary conditions and were provided with centralized system of water supply and centralized sewage system $-32.6 \%(p<0.05)$. Another $14.6 \%$ of peasants were residents in the suburban houses $(\mathrm{p}<0.001)$ and $2.66 \%$ - in the detached houses $(\mathrm{p}<0.001)$.

The household conditions of city-dwellers can be described as follows: $40 \%$ lived in apartments $(\mathrm{p}<0.05)$, $7.33 \%$ - in the detached houses $(\mathrm{p}<0.001)$ and $2.66 \%$ - in suburban houses $(\mathrm{p}<0.001)$.

We carried out hygienic estimation residents' appartment by the quantity of floors. The majority of peasants lived in the high-style appartments: from $6-16$ storeys $38.6 \%$ to $1-$ 5 storeys flats $26.6 \%$. Another $29.3 \%$ of peasants were residents of the comfortable $1-5$ storeys suburban houses $(p<0.001) ; 5.33 \%$ of peasants lived in the cottages $(p<0.001)$. City-dwellers were provided with comfortable housing with centralized water system. Mostly, city-dwellers were located in the $6-16$ storeys flats: $52 \%$; in the cottages $-28 \%(\mathrm{p}<0.001) ; 5.33 \%$ - in the suburban houses $(\mathrm{p}<$ $0.001)$.

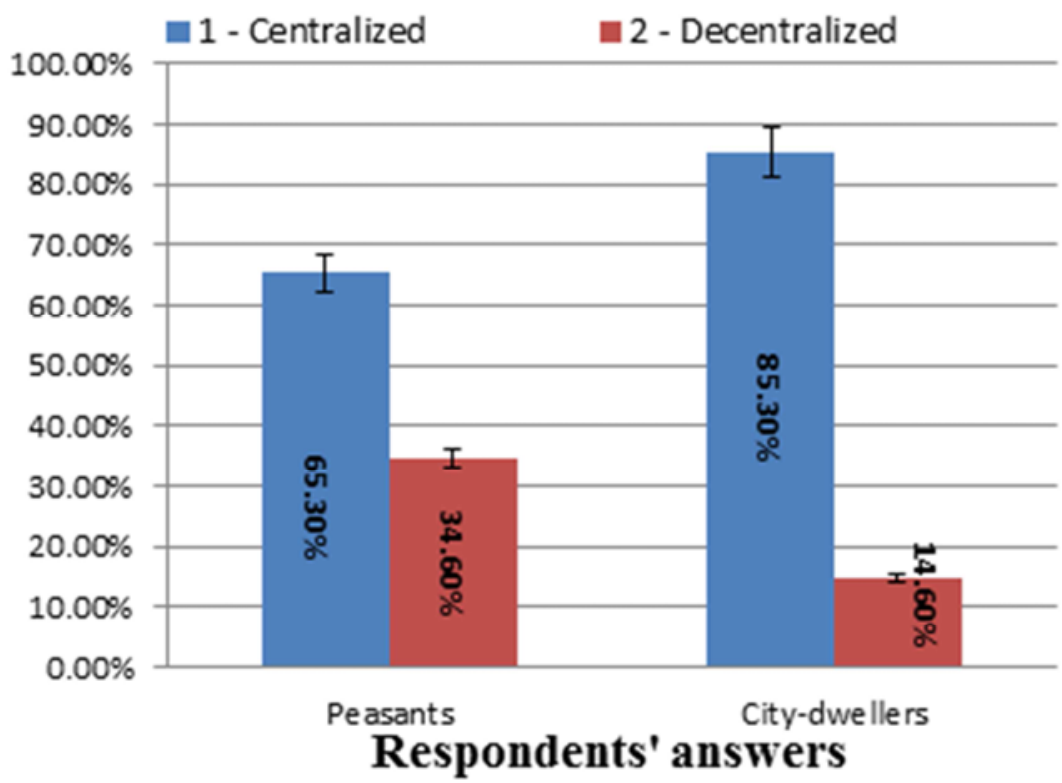

Figure 3. Frequency of respondents' answers in the experimental and control groups on the question: What type of sewerage system is carried out in Your community?"( $P \pm m p \%)$. 
Table 7. Respondents' answers from Central zone of urbanization on the question How many persons living in the Your apartment?"(absolute,\%).

\begin{tabular}{lll}
\hline Proposed variant of answer & Peasants & City - dwellers \\
\hline 1 person & $6(8.0 \%)$ & $2(2.66 \%)$ \\
2 persons & $21(28 \%)$ & $26(34.6 \%)$ \\
3 persons & $20(26.6 \%)$ & $21(28 \%)$ \\
4 persons & $17(22.6 \%)$ & $21(28 \%)$ \\
$5-6$ persons & $11(14.6 \%)$ & $5(6.66 \%)$ \\
Totally (n=150) & $75(100 \%)$ & $75(100 \%)$ \\
p & $\mathrm{p}=0.241$ & \\
\hline
\end{tabular}

Note. $\mathrm{p}$ - significance of differences between respondents answers in the experimental and control groups by a criterion $\chi^{2}-$ Pearson.

Results of sociological survey have been shown, that distribution by the quantity of respondents per 1 flat was following: 2 peasants per 1 flat $-28 \% ; 3$ peasants per 1 flat $26.6 \%$; 4 peasants per 1 flat $-22.6 \% ; 5-6$ peasants per 1 flat
$-14.6 \%$; 1 peasant per 1 flat $-8.0 \%(\mathrm{p}<0.05)$. Most of citydwellers lived on 2 people, as shown $34.6 \%$ of respondents; 3 city-dwellers per 1 flat $-28 \%$; 4 city-dwellers per 1 flat $28 \% ; 5-6$ city-dwellers per 1 flat $-6.66 \%$; single respondents $-2.66 \%(\mathrm{p}<0.05)$ (table 7$)$.

From hygienic point of view, we carried out analize quntity of water sinks in the apartments: $68 \%$ of peasants have been provided with 2 sinks; $13.3 \%$ - with 1 sink; $10.6 \%$ -3 sinks $(\mathrm{p}<0.001)$. Minority of peasants in the rural settlements having $5-6$ sinks $-5.33 \%$. Similar trend was observed among city-dwellers: 64\% was provided with 2 sinks; another $22.6 \%$ of respondents used 3 sinks $(\mathrm{p}<0.001)$. On average 1 sink was located in the apartments of $13.3 \%$ of respondents in the control group.

Structure of water users by daily intake of drinking water is presented on (Figure 4).

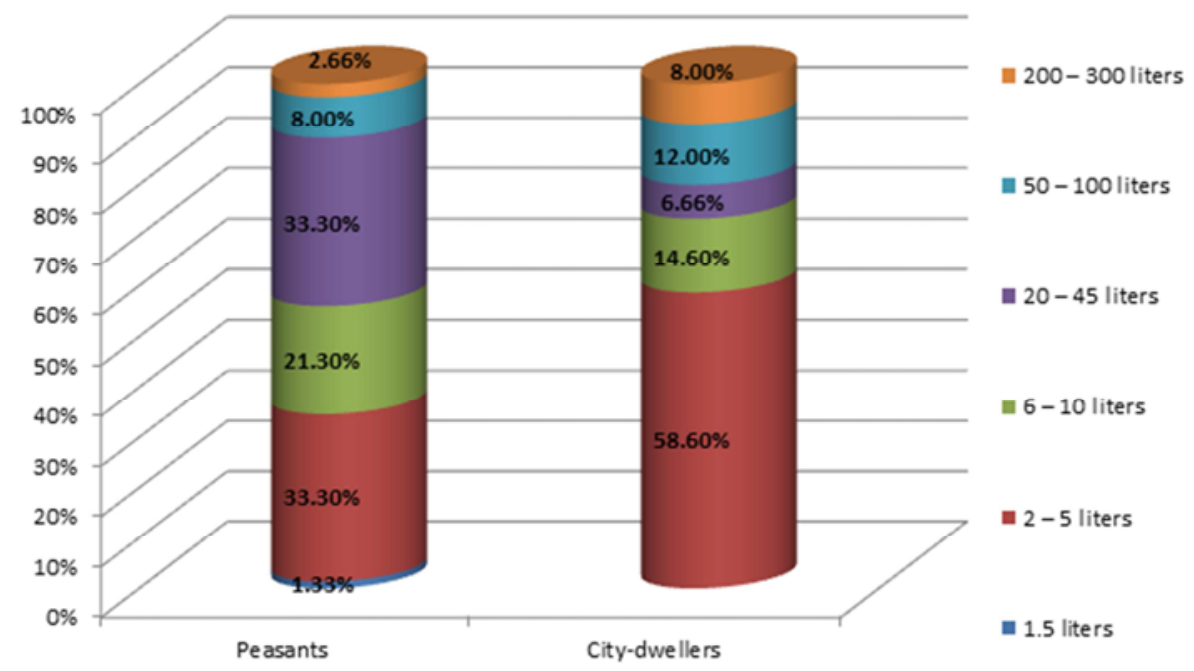

Figure 4. Structure of daily consumption of drinking water among rural and urban residents in Dnipropetrovsk region, litres/day.

First rank position among city-dellers carried out $58.6 \%$ of respondents, using drinking water $2-5$ liters per day on average $(\mathrm{p}<0.05)$. Second rank takes the following $14.6 \%$ of respondents, consuming from 6 to 10 liters of water $(\mathrm{p}<0.001)$. On the third place, as shown were located $12.0 \%$ of city-dwellers, which used up to 50-100 liters of water per day. Only $8.0 \%$ of respondents used 200-300 litres of drinking water for a day $(\mathrm{p}=0.242)$.

Table 8. Daily drinking water intake, liters per day (absolute,\%).

\begin{tabular}{lll}
\hline Proposed variant of answer & Peasants & City - dwellers \\
\hline 1.5 liters & $1(1.33 \%)$ & 0 \\
$2-5$ liters & $25(33.3 \%)$ & $44(58.6 \%)$ \\
$6-10$ liters & $16(21.3 \%)$ & $11(14.6 \%)$ \\
$20-45$ liters & $25(33.3 \%)$ & $5(6.66 \%)$ \\
$50-100$ liters & $6(8.0 \%)$ & $9(12.0 \%)$ \\
$200-300$ liters & $2(2.66 \%)$ & $6(8.0 \%)$ \\
Totally $(\mathrm{n}=150)$ & $75(100 \%)$ & $75(100 \%)$ \\
$\mathrm{p}$ & $\mathrm{p}=0.242$ & \\
\hline
\end{tabular}

Note. $\mathrm{p}$ - significance level of differences by daily consumption of drinking water (litres/day) in the experimental and control groups by a criterion $\chi^{2}-$ Pearson.
Probably, peasants consumed 20-45 litres of drinking water per day $33.3 \%$. Daily intake of drinking water from $6-$ 10 liters per day was observed at $21.3 \%$ of peasants; from 50 to 100 liters $-8.0 \%$. Daily consumption of drinking water was varied at the minority of peasants: 1.5 liters per day $1.33 \%$; 200-300 liters consumed $-2.66 \%$ of respondents (table 8).

\subsection{Analysis Correlation Links Between Indicators of Water Quality and Morbidity of Children in the Rural Tacsons of Dnepropetrovsk Region}

Results of our research have been shown correlation links between diseases of children with significant influence in the centralized drinking water sources of the 1 tacson - dry residue, chlorides and sulfates: average correlation $(\mathrm{r}=0.50$, $\mathrm{p}<0.05)$; in the 2 tacson - total hardness $(\mathrm{r}=0.82)$; dry residue, chlorides, sulfates, calcium and magnesium - strong correlation $(\mathrm{r}=0.83, \mathrm{p}<0.05)$; in the 3 and 4 tacsons: dry residue, chlorides, sulfates, calcium, magnesium -an average correlation $(\mathrm{r}=0.50, \mathrm{p}<0.05)$; in the 5 tacson: dry residue, chlorides, sulfates, calcium, magnesium and iron $(\mathrm{r}=0.50$, 
$\mathrm{p}<0.001$ ); in the 6 tacson: dry residue, chlorides, sulfates, calcium and magnesium -strong correlation $(\mathrm{r}=0.87$, $\mathrm{p}<0.05$ ).

Analysis of the morbidity among peasants - children in the 1 tacson allowed to revealed strong and average correlation links between tumors with calcium and magnesium $(r=0.43$, $\mathrm{p}<0.05)$, anemia - with calcium and magnesium $(\mathrm{r}=0.32$, $\mathrm{p}<0.05$ ), diseases of the nervous system - with calcium and magnesium $(\mathrm{r}=0.35, \mathrm{p}<0.05)$, diseases of the circulatory system - with calcium, magnesium, iron $(r=0.87, p<0.05)$, digestion organs diseases - with dry residue, chlorides, sulfates $(\mathrm{r}=0.39, \mathrm{p}<0.05)$, respiratory system diseases with total hardness $(\mathrm{r}=0.78, \mathrm{p}<0.05)$, dry residue, chlorides, sulfates $(r=0.63, p<0.05)$. Significantly strong correlation was found between dry residue, chlorides, sulfates and the following diseases: skin and subcutaneous tissue $(\mathrm{r}=0.71, \mathrm{p}<0.05)$, musculoskeletal system $(\mathrm{r}=0.78, \mathrm{p}$ $<0.05)$, urinary system $(\mathrm{r}=0.87, \mathrm{p}<0.05)$. On the other hand, content of calcium, magnesium and iron in the drinking water of centralized sources caused a strong relationship of congenital anomalies $(r=0.74, p<0.05)$ and congenital anomalies of the circulatory system $(r=0.77, p<0.05)$ among children, living in this tacson.

In the 2 tacson you should pay attention to the strong correlation link between neoplasm's at the 14 y.o. children with iron $(\mathrm{r}=0.87)$, blood and hematopoietic organs diseases - with total hardness $(\mathrm{r}=0.78)$ and iron $(\mathrm{r}=0.74)$, anemia with iron $(r=0.79)$, endocrine system diseases - with total hardness $(r=0.88)$, dry residue, chlorides, sulfates, calcium and magnesium $(\mathrm{r}=0.83)$, diseases of the respiratory system - with total hardness, dry residue, chlorides, sulfates, calcium and magnesium $(\mathrm{r}=0.73)$, congenital anomalies - with iron $(\mathrm{r}=0.74)$, congenital anomalies of blood circulation organs - with iron $(r=0.77)(p<0.05)$.

Analysis of correlation links, conducted among children in the 3 tacson have been shown a significantly high relationship between: neoplasm's - with iron content $(\mathrm{r}=0.87)$, blood and hematopoietic organs diseases - with total hardness $(\mathrm{r}=0.78)$, dry residue, chlorides, sulfates, calcium and magnesium $(\mathrm{r}=0.32)$, iron $(\mathrm{r}=0.95)$, anemia with total hardness $(\mathrm{r}=0.58)$ and iron $(\mathrm{r}=0.79)$, endocrine system diseases - with total hardness $(\mathrm{r}=0.88)$, dry residue, chlorides, sulfates, calcium, magnesium $(\mathrm{r}=0.74)$ and iron $(r=0.93)$, nervous system diseases - with iron $(r=0.87)$, circulatory system diseases - with iron $(r=0.74)(p<0.05)$. Significantly strong correlation in this tacson was observed between disease of the respiratory system and total hardness ( $\mathrm{r}=0.87)$, dry residue, chlorides, sulfates, calcium, magnesium $(r=0.95)$, congenital anomalies of the circulatory system - with iron content $(r=0.87)(p<0.05)$.

In the 4 tacson to the children was significantly impact: iron - on the tumors and hematopoietic organs diseases $(\mathrm{r}=0.87)$, anemia and nervous system diseases $(\mathrm{r}=0.95)$, cardiovascular diseases $(\mathrm{r}=0.93)$, congenital anomalies $(\mathrm{r}=0.87)$, i.e. anomalies of the circulatory system $(\mathrm{r}=0.71)$; total hardness - on the respiratory system diseases $(r=0.87)$ and also dry residue, chlorides, sulfates, calcium and magnesium $(r=0.84)(p<0.05)$.

In the water of 5 tacson was determined a strong correlation between incidence of children diseases as well as hematopoietic organs diseases - with total hardness $(\mathrm{r}=$ 0.78), anemia - with overnormal content of chlorides and sulfates $(\mathrm{r}=0.87)$, endocrine system diseases - with dry residue $(\mathrm{r}=0.87)$, respiratory system diseases - with dry residue, chlorides, sulfates, calcium and magnesium $(\mathrm{r}=0.83)$ $(\mathrm{p}<0.05)$.

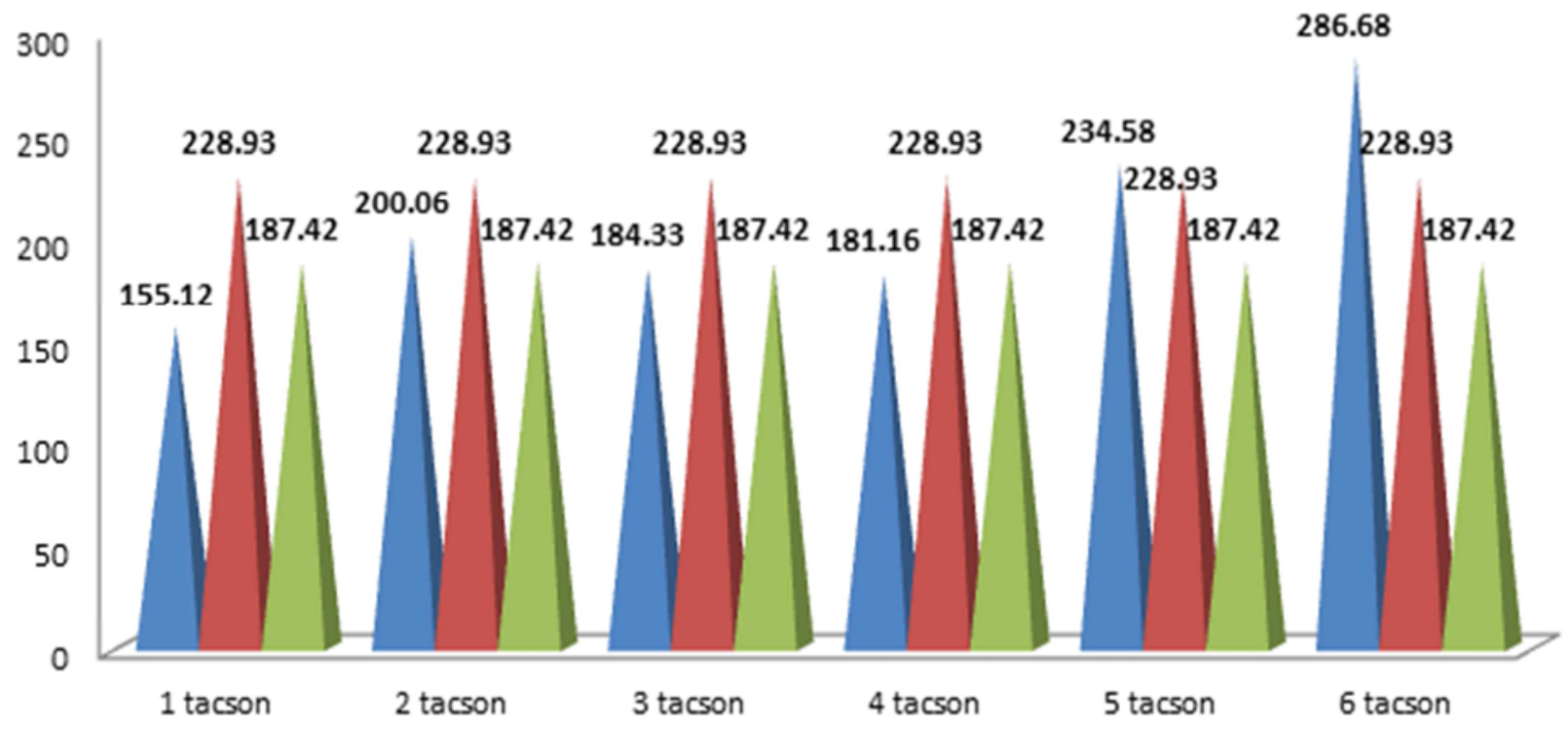

= 2008-2013 average indicator by districts $\quad$ ava age indicator by region

Figure 5. Anemia cases at 14 y.o. children, by average annual indicators, in the separate tacsons of Dnepropetrovsk region during 2008-2013 years (cases per 10000 children). 
The majority of drinking water quality indicators in the 6 tacson were significantly influence with average and strong correlation to the diseases level: total hardness - on the hematopoietic organs diseases $(r=0.78)$, anemia $(r=0.58)$, diseases of the endocrine system $(r=0.49)$, circulatory system $(r=0.39)$, respiratory $(r=0.82)$, digestion system $(r=$ $0.65)$, skin and subcutaneous tissue $(\mathrm{r}=0.58)$, musculoskeletal system $(r=0.42)(p<0.05)$. Similar trend was observed between iron content and such diseases at the children - tumors $(r=0.87)$, hematopoietic organs $(r=0.74)$, anemia $(r=0.79)$, diseases of the endocrine and nervous systems $(r=0.80)$, circulatory system $(r=0.78)(p<0.05)$ (Figure 5).

In all rural tacsons of Dnepropetrovsk region was shown common tendency of strong correlation between some chemical indicators of drinking water quality $(\mathrm{Zn}, \mathrm{Cu}, \mathrm{Mn}$, $\mathrm{pH}, \mathrm{F}, \mathrm{Al}$, nitrogen ammonia, nitrites, nitrates and oxidability) and morbidity of 14 y.o. children with the following diseases: in the 1 tacson - with circulatory system $(\mathrm{r}=0.87)$; in the 3 tacson - with tumors $(\mathrm{r}=0.87)$, hematopoetic organs diseases $(r=0.74-0.95)$, anemia $(r=$ $0.79-0.87)$, diseases of the nervous $(r=0.87)$ and circulatory $(\mathrm{r}=0.74-0.95)$ systems, congenital anomalies of the circulatory system $(\mathrm{r}=0.87)$; in the 4 tacson - with tumors $(\mathrm{r}=0.87)$, hematopoetic organs $(\mathrm{r}=0.87)$, anemia $(\mathrm{r}$ $=0.74-0.95)$, congenital anomalies $(\mathrm{r}=0.87)$; in the 5 tacson - with tumors $(\mathrm{r}=0.87)$, blood and organs of hematopoiesis $(\mathrm{r}=0.74-0.95)$; in the 6 tacson - with tumors $(\mathrm{r}=0.87)$, hematopoetic organs diseases $(r=0.74-0.95)$, anemia $(r=$ $0.79-0.87)$, circulatory system $(r=0.75-0.78)(p<0.05)$.

Average correlation between infectious diseases at the children, used drinking water from centralized water supply sources in the 2 tacson and the following chemical substances: $\mathrm{Zn}, \mathrm{Cu}, \mathrm{Mn}, \mathrm{F}, \mathrm{Al}$, nitrogen ammonia, nitrites and nitrates was revealed $(\mathrm{r}=0.30, \mathrm{p}<0.05)$.

In the drinking water of 1 tacson were strongly correlated levels of the following diseases among 14 y.o. children: congenital anomalies - with all chemical indicators, which characterized drinking water quality $(\mathrm{Zn}, \mathrm{Cu}, \mathrm{Mn}, \mathrm{F}, \mathrm{Al}$, nitrogen ammonia, nitrites, nitrates), except $\mathrm{pH}$ and oxidability $(\mathrm{r}=0.74)$, i.e. congenital anomalies of circulatory system $(r=0.77)(p<0.05)$. In the 2 tacson all chemical parameters, except $\mathrm{pH}$, were strongly correlated with tumors $(\mathrm{r}=0.87)$, hematopoetic organs diseases $(\mathrm{r}=0.74-0.89)$, anemia ( $\mathrm{r}=0.79-0.87)$; in the 4 tacson -all chemical parameters, except $\mathrm{pH}$ and nitrate, correlated with diseases of nervous $(\mathrm{r}=0.87-0.95)$ and circulatory system $(\mathrm{r}=0.83-$ 0.93 ); in the 5 tacson all chemical parameters, except $\mathrm{pH}, \mathrm{F}$ and nitrate correlated with diseases of nervous $(\mathrm{r}=0.80-$ $0.83)$ and circulatory system $(\mathrm{r}=0.80)$; in the 6 tacson - all chemical parameters, except $\mathrm{pH}$, were correlated with endocrine $(\mathrm{r}=0.80-0.83)$ and nervous system diseases $(\mathrm{r}=0.80)$ among children $(\mathrm{p}<0.05)$. A strong correlation between diseases of endocrine $(\mathrm{r}=0.83)$ and respiratory system with $\mathrm{pH}$ was revealed $(\mathrm{r}=0.73)$ in the 2 tacson; diseases of endocrine system correlated with $\mathrm{pH}, \mathrm{F}$, nitrates and oxidability - in the 3 tacson $(r=0.83-0.93)(p<0.05)$.

\section{Conclusions}

During 2012 - 2014 years our study showed significant trend towards increasing useage of drinking water purifiers, primary, for drinking purposes, among the peasants and citydwellers in Dnipro city.

Peasants in the Dnepropetrovsk region (Ukraine) have been performed deterioration quality of piped drinking water as well as smell $-22.6 \%$, color $-14.6 \%$, rust $-13.3 \%$, precipitate $-8.0 \%$, turbidity and suspended solids $-10.6 \%$, taste and aftertaste $-13.3 \%$, foam and impurities $-10.6 \%$ $(p<0.05)$. Minority of peasants $-6.66 \%$ consider "problem with drinking water quality does not exist".

Our study indicates increasing of daily consumption of drinking water, which was related to the peasants' population: from $2-5$ liters/daily $(33.3 \%)$ to $20-40$ liters/daily $(33.3 \%)$. On the other hand, the study results provided tendency to decrease piped water among citydwellers $(14.6 \%)$ on average $6-10$ liters/daily $(\mathrm{p}<0.001)$ and significant trend to increase consumption of bottled water $(29.3 \%)$ or domestic filters $(33.3 \%)$ in Dnipro city $(\mathrm{p}<0.05)$.

This study indicates that peasants' population has been covered by centralized system of water supply and centralized sewage system $(32.6 \%)(\mathrm{p}<0.05)$. Other peasants $(34.6 \%)$ were covered with decentralized sewage systems. Majority of peasants lived in the $6-16$ storeys apartments $(38.6 \%)$.

Correlation between chemical and mineral composition of drinking water from centralized water supply sources and morbidity among 14 y.o. children by the separate classes of diseases: neoplasm - with high iron content in the 3 and 4 tacsons $(r=0.87)$; hematopoetic organs diseases - with total hardness in the 2, 3, 5, 6 tacsons $(\mathrm{r}=0.78)$; anemia - with total hardness $(r=0.58)$ and iron content $(r=0.79)$ in the 3,6 tacsons; anemia - with iron $(\mathrm{r}=0.95)$ in the 4 tacson; anemia - with high content of chlorides and sulfates $(r=0.87)$ in the 5 tacson $(\mathrm{p}<0.05)$.

Correlation between some heavy metals in the drinking water and incidence of diseases among children was revealed: congenital anomalies - with $\mathrm{Zn}, \mathrm{Cu}, \mathrm{Mn}, \mathrm{F}, \mathrm{Al}$, nitrogen ammonia, nitrite, nitrate $(r=0.74)(p<0.05)$ in the centralized water sources of the 1 tacson.

\section{References}

[1] Colabianchi N., Turner L., Hood N. E., Chaloupka F. J., Johnston L. D., Availability of drinking water in U.S. public school cafeterias. Electronic book. - Chicago, 2014. - 150 p.

[2] Pons W, Young I, Truong J, Jones-Bitton A, McEwen S, Pintar K, Papadopoulos A., A Systematic Review of Waterborne Disease Outbreaks Associated with Small Non-Community Drinking Water Systems in Canada and the United States, Environ Monit Assess. 2016 Dec; 188 (12): 680. 
[3] Water and health in Europe: a joint report from the European Environment Agency and the WHO Regional Office for Europe. Udited by Bartram Jamie et al. WHO Regional publications European series. World Health Organization: Copenhagen, 2002. - Vol. 93. - 222 p.

[4] Prasad N. R., Child survival in rural areas. Book. - New Delhi, India: Anmol. Publications, 1997. - 196 p.

[5] Water quality criteria. Drinking water health advisories. Washington: U.S. Environmental Protection Agency, 2005.Electronic Book [Asses mode] http://www.epa.gov/waterscience/drinking/

[6] Rahman A, Hashem A, Nur-A-Tomal S., Potable water quality monitoring of primary schools in Magura district, Bangladesh: children's health risk assessment, J Environ Sci Health A Tox Hazard Subst Environ Eng. 2011; 46 (11): 1163-76.

[7] Maity JP, Nath B, Chen CY et al., Arsenic-enriched groundwaters of India, Bangladesh and Taiwan - comparison of hydrochemical characteristics and mobility constraints, J Water Health. 2016 Dec; 14 (6): 998-1008.
[8] Aktymbayeva A. S., Ableeva A. G., Aktymbayeva B. I., Evaluation of Alakol Lake Ecosystem Sustainability Under Conditions of Antropogenic Buren in the Basin Proceedings of the IWA 6th Eastern European Young Water Professionals Conference "EAST Meets WEST" Istanbul 2014; 150-168.

[9] Talanov E. A., Aktymbayeva A. S., Modeling of change of a mineralization of water and ecological condition of Alakol lake, Materials of the international symposium Strategy and methods of an assessment of an environmental risk of arid and mountain territories." Alma-Ata 2001; 109-117.

[10] Hryhorenko L. V., Hygienic assessment of water quality from the channel "Dnipro-Kryvyi Rih" as well as the source of centralized water supply peasants' population in Dnepropetrovsk region, Hygiene of settlements. 2013; 62: 9299.

[11] Hryhorenko L. V., Potable water quality in the Karachunyvskyi reservoir, Austrian Journal of Technical and Natural Sciences. 2014; 1: 40-45. 